\title{
New Lights on the Root / Family of the Ancient Egyptian Word 'swh'
}

\section{Mohamed Gamal Rashed \\ Damietta University, Egypt}

Mohamedgamal_1@yahoo.com

\begin{abstract}
The article shed new lights on the Egyptian term ' $s w h$ '. It discussed the root of the term, meanings, and its frequent use. It investigated all possible derived words and their origins to determine the words derived from the term and these that derived from later acquired meanings. The article dealt with the words in a lexicographical study discussing the different orthographies, attestations, primary meanings, the significances and the metaphoric use of each of the derived words. The article draws on the word-tree in the Egyptian language. How a term might gain new meanings; and how new meaning of a term can be used later independently as a new root gaining new independent meanings.
\end{abstract}

Keywords: Egg - Root - Offspring - Coffin - Metaphor - Sun Disk - Mother Womb Primeval Cosmos - Mummy Wrapping

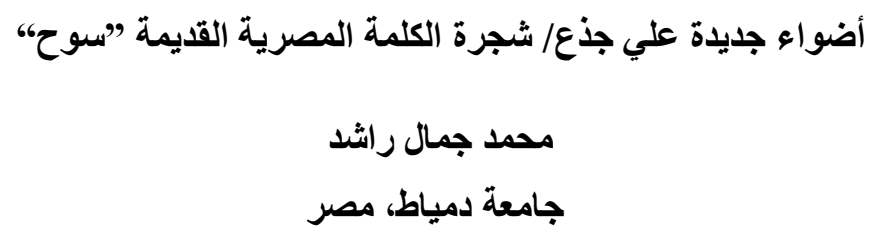

Mohamedgamal_1@yahoo.com

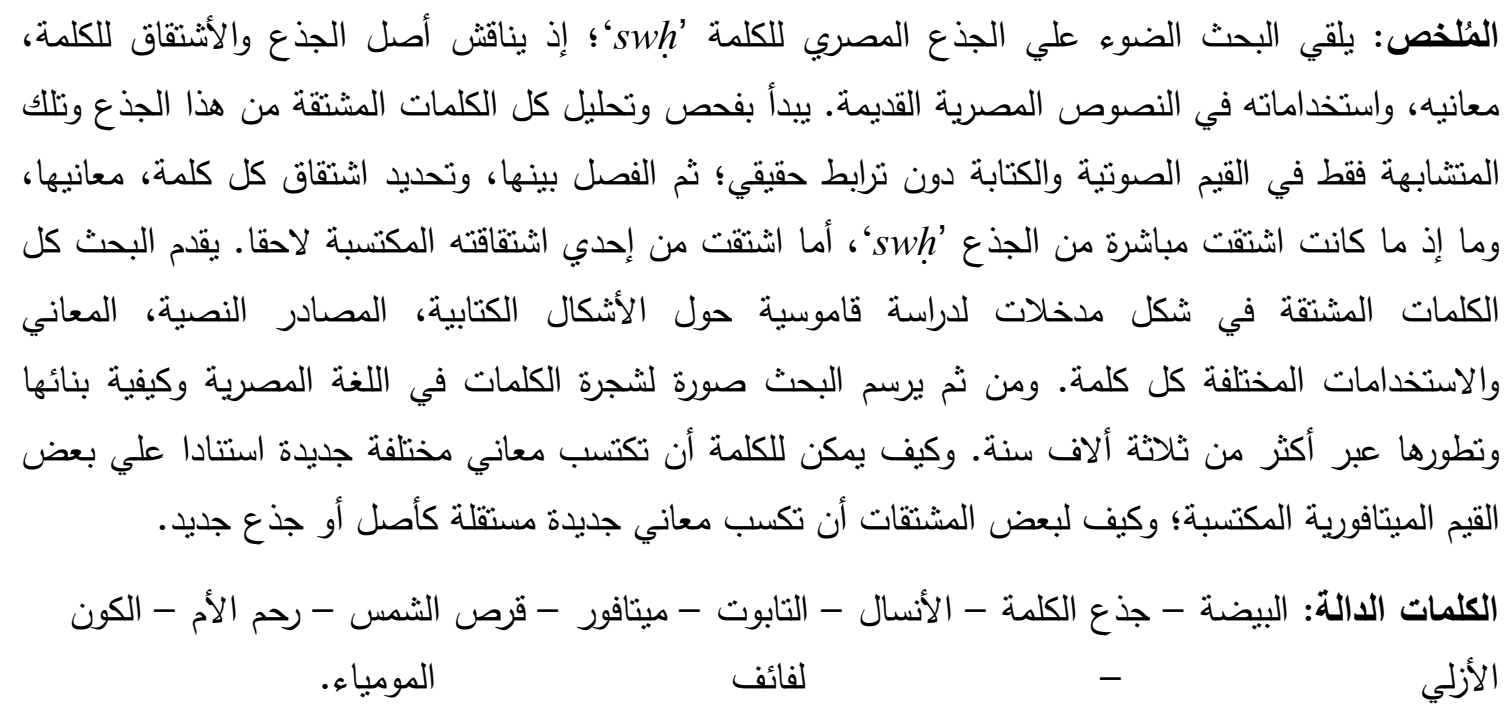


The Egyptian Language offers a range of terms that each refers to several meanings. Despite the original root, the accurate meaning is often difficult to ascertain due to problematic etymology, origin, and frequent use of the term. Often, terms transferred semantically from the original meaning into new acquired meaning(s). Thus, a new acquired meaning might become independent in the course of time and its frequent use, and accordingly, it is treated as an origin. Each term has its own case that requires examination in order to assert or deny a certain meaning to its root, and whether there is a metaphorical connection to the newly acquired meanings or not. Thus for, it requires to study the attestations, frequent use, derivations, and relevant contexts of each term.

The article discusses the Egyptian term ' $s w h$ ', its meanings, and the derived words. Some words are derived from the origin of the term, while others derived from its later acquired meanings. The derived words include, for example, 'swh.t' a noun that means 'egg', but also it occurs occasionally with some other meanings such as 'inner coffin,', 'bowl,', 'son'. Among the derived words, one may counts 'swh(w), garment,' 'swh(.w), and 'swh.ty,' 'divine names,' and 'swhw,' a 'personal name'. In Hieroglyphs, the intended meaning of terms, and/ or their derivations, are often determined with a sign expressing the meaning 'a determinative'. The determinative in use for each of the derived words of ' $s w h$ ' gives a distinguished meaning, which is associated with the origin of 'swh'. For example, 'swh.t, egg' is metaphorically derived from 'swh,' however; it acquired other meanings 'see infra.' On several other occasions, 'swh.t' occurred with alternative determinatives. Each determinative often determines a different meaning such as 'wrappings, inner coffin' which is often determined with the sign , together with the egg sign 'see infra.'

It is noted that some terms might acquire new meanings that reflect the changes happening in linguistics over time. Wherein the meaning of the sense of a word which was used as a portion of a popularized metaphorical phrase is transferred back to and subsequently becomes one of the accepted meanings of the original word. This is the case of the term ' $s w h$ ', as it is discussed hereafter. Though, the term is attested frequently but its meaning raises a number of questions. Osing returned its origin to the meaning of "to enshroud, ${ }^{3}$ however, other meanings are possible. The article discusses

* My sincere thanks are due to Prof. Dr. Ursula Verhoeven-Van Elsbergen, and to Prof. Dr. Dagmar Budde (Johannes Gutenberg University Mainz) for their comments and reviews of an earlier draft of this paper. The article has its first draft prepared during a Post-doctorate at Johannes Gutenberg University Mainz and with the support of the DAAD.

${ }^{1}$ WB IV, 74.4; R. Hannig, Grosses Handwörterbuch Ägyptisch-Deutsch die Sprache der Pharaonen (2800-950 v. Chr.). Kulturgeschichte der Antiken Welt 64. (Mainz: Philipp von Zabern,1995), 680; H. L. Lesko, A Dictionary of Late Egyptian, II (USA: Providence, RI: Scribe Publications, 2002), 21; P. Wilson, A Ptolemaic Lexikon: A Lexicographical Study of the Texts in the Temple of Edfu, OLA 78 (Leuven: Peeters 1997), 812; FCD 217.

2 WB IV, 74.3; Hannig, Grosses Handwörterbuch Ägyptisch-Deutsch, 680; E. Edel, "Beiträge zu den Inschriften des Mittleren Reiches in den Gräbern der Qubbet el Hawa," MÄS 25 (1971): Abb.10 (middle register, 4th column). This reading is uncertain, and probably incorrect since the occurrence on which the dictionary of Berlin relying is for ' $w 3$ h.t', not 'swh.t'.

3 In his comments on the nominal building of 'swh.t'. J. Osing, Die Nominalbildung des Ägyptischen. Textband. Deutsches Archäologisches Institut, Abteilung Kairo 3 (Mainz: Philipp von Zabern, 1976), 64. 
the term ' $s w h$ ', its origin, possible meanings, and its derivations as well as mapping the possible metaphorical relations between the origin and its acquired meanings. It puts together the entries for these different meanings and derived words. Furthermore, the semantic derivation of each derived word or acquired meaning is examined in order to understand the frequent use of the term in the Egyptian language and writing.

\section{The origin of the term ' $s w h$ '}

The term ' $s w h$,' is tri-radical verb, consists of three consonants. Osing translate this verb as 'einhüllen, (to enshroud, enwrap, wrap, envelope), ' from which derived the female noun 'swh.t, egg'. Although its etymology and structure have been examined, the original meaning of its root has not fully determined yet due to inadequate earlier attestations. The meaning that Osing provided is still preferred; however, other possible meanings are suggested. All the possible meanings of the root, together with the available attestations are discussed hereafter.

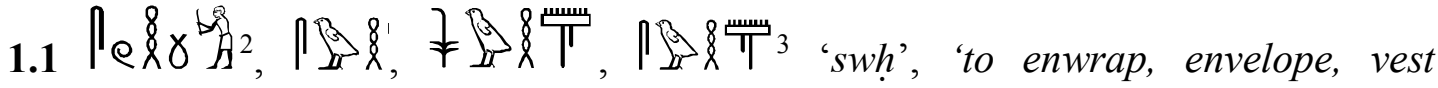
(oneself),'

The verb is attested from the PT onwards in this meaning, and with the meaning 'einhüllen, 'to wrap, wrap up, enfold, envelope, cover', with certain orthographies such as 78.8 and $\bar{e} \gamma{ }^{5}$ It is often determined with a hieroglyph of a cloth, e.g. A noun form, derived from the term, is also attested in the meaning 'garment, wrapping,' 'see infra'. ${ }^{6}$ The term ' $s w h$ ', as well as its noun form, occurs frequently in the funeral and religious texts, from the PT onwards, particularly in the mourning ceremonies. ${ }^{7}$ It occurs also in a hymn addressed to the god of the Nile on a Ramesside ostracon (DeM 1675), ${ }^{8}$ which reads:

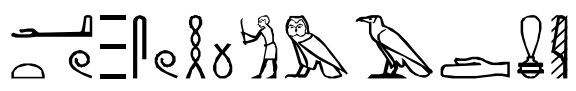

${ }^{1}$ Osing, Die Nominalbildung des Ägyptischen, 64.

2 D. Meeks, Alex. 78.3703; H.W. Fischer-Elfert, Literarische Ostraka der Ramessidenzeit in Übersetzung. Kleine ägyptische Texte [9]. (Wiesbaden: Harrassowitz, 1986), 42 (n.49), 44 (n.1).

3 WB IV, 72.4; Pyr. 726a; Lesko, A Dictionary of Late Egyptian, II, 21.

${ }^{4}$ Osing, Die Nominalbildung des Ägyptischen, 64.

5 WB IV, 72.5-6; Pyr. 726a; Lesko, A Dictionary of Late Egyptian, II, 21.

${ }^{6}$ WB IV, 72.3; Pyr. 726a; Fischer-Elfert, Literarische Ostraka, 42 (n.49), and 44 (n.1); Hannig, Grosses Handwörterbuch Ägyptisch-Deutsch, 680; R. Van Der Molen, A Hieroglyphic Dictionary of Egyptian Coffin Texts, Probleme der Ägyptologie 15. (Leiden: Brill, 2000), 465; Lesko, A dictionary of Late Egyptian, II, 21; Laisney, Aménémopé, 168, Anm. 979.

${ }^{7}$ Pyr. 726.

${ }^{8}$ G. Posener, Catalogue des ostraca hiératiques littéraires de Deir el Médineh. Tome III (fasc. 3): nos. 1607-1675. Documents de fouilles de l'Institut français d'archéologie orientale 20 (3). (Le Caire: Institut français d'Archéologie orientale, 1938), pls. 81-84; J.F. Borghouts, 'Review of G. Posener, Catalogue des Ostraca Hiératiques Littéraires de Deir El Médineh III, Nº 1607-1675, 'CDE 58 (1983), 114; Fischer-Elfert, Literarische Ostraka, $31 \mathrm{ff}$. 


\section{'c. $t$ ( $m$ ) swh $m$ 3dmj', 'The limbs are covered with red linen.,"}

The term in the same context occurs again in Dendara ${ }^{2}$ from the Ptolemaic-Roman Period, where it also has the meaning of 'covering (/ wrapping) the limbs. ${ }^{3}$ In the latter occurrences, it is determined with a sign, represents 'a man holding a stick', and which expresses that limbs are covered or wrapped firmly.

$$
1.2 \overbrace{}^{e}{ }^{\complement} \text { 'swh', 'to create, form' }
$$

The verb occurs in this meaning at the temple of Philae from the Ptolemaic-Roman

Period, ${ }^{5}$ while no earlier occurrence is known. It is determined with the sign forearm with a stick', 6 a sign which determines 'force, effort' in the meaning of words. It has been noted that creation is an action that requires the force and effort of the creator in order to mold the creatures on his wheel or inside the mother-womb. Perhaps, the word gained this meaning from the proper imagery of the creator god who pedals the wheel to mold/ form the creatures. This has been described widely in the cosmogonic texts. ${ }^{7}$ Thus, it can be assumed that this meaning and use of ' $s w h$ ' has been gained from its root in the meaning 'to vest, envelope, etc., which has been given in the previous entry, and then, it becomes an independent meaning in its use.

In the meaning 'to create, form', it occurs in several occasions from the Late Periods. The text of Philae describes the proper activities of Ptah-Tatenen, ${ }^{8}$ who is molding the creatures on his potter's wheel. ${ }^{9}$ In this text, the god forms ( $\left.s w h\right)$ the water (the sperm), and knots it inside the mother's womb to produce the egg where the text reads:

\footnotetext{
${ }^{1}$ Fischer-Elfert, Literarische Ostraka, 42 (n.49). Elfert commented on the word ' $3 d m y$ or idmy' that it is mostly a red festival divine vest.

2 Dendara III, 12,5 and 8; Meeks, Alex. 78.3703.

${ }^{3}$ Fischer-Elfert, Literarische Ostraka, 44 (n.1).

4 WB IV, 72.8; Philä II, 181, 2-3.

5 Philä II, 181, 2-3.
}

6 A. Gardiner, Egyptian Grammar (Oxford: Oxford University Press, 1950), 455; J.P. Allen, Middle Egyptian. an introduction to the language and culture of hieroglyphs, 2nd, revised ed. (Cambridge: Cambridge University Press, 2010), 429. It also replaces the man holding a stick which occasionally determines the term in the meaning 'to vest, wrap up'.

7 Cf. M.G. Rashed, "The Four Primeval Elements of Creation according to the Philosophy of Hermopolis: A new Interpretation of their Origin," in D. Minacci, M. Betro, St. Quirke (eds.), Company of images: modelling the ancient Egyptian imaginary. World of the Middle Kingdom (2000$1500 \mathrm{BC}$ ), OLA 262 (2017): 377-94. In numerous occasions, the cosmogonic texts describe the action of creation with the expression ' $\mathrm{km} 3 \mathrm{swh.t}$ ', since the egg is a metaphor for creation and creatures. D. Mendel, Die kosmogonischen Inschriften in der Barkenkapelle des Chonstempels von Karnak, MRÉ 9 (Turnhout: Brepols. 2003), 44ff.

${ }^{8}$ Often Khnum, the potter, who molds the creatures. Cf. S. Sauneron, Les Fêtes Religieuses d'Esna aux derniers siecles du paganisme. Esna V (Le Caire: IFAO, 1968), 235 ('O, God of the wheel, who fashions the egg ( $\mathrm{km} 3 \mathrm{swh.t}$ ) on his wheel'). S. Sauneron, Le Temple d'Esna III, (Le Caire: IFAO, 1962), 246, text 320.21; also, P. Dorman, Faces in Clay, MÄS 52 (2002), 117.

9 Ptah-Tatenen is represented twice fashioning an egg on his wheel at Philae, which comes in a variation of molding the child god, mankind, or creatures. G. Bénédite, Le Temple de Philä, MMAF 13/2 (Le Caire: IFAO, 1895), pl. 61. This is a rare scene depicting Khnum, or Ptah instead, working at his 


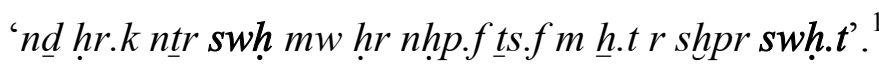

'Heal to you, God, who turns water (/ creates seed), upon his potter's wheel, who knots (it) inside the belly (mother womb), in order to bring the egg into being'.

Here, the term has a metaphorical connection to the egg of creatures. In a comparison, comes also the text of Esna, which reads: 'who knots the egg inside the body (womb) of the women (ts swh.t $m \underline{h t} n h m w t)$. ${ }^{2}$ In another text accompanying the scene of the divine potters from Kellis at Dakhleh Oasis, Ptah, the creator god, is attributed with the fashioning of the egg, where the text reads:

'Pth rsy-inb.f nb 'nh-t3wy kd swh.t m-

'Ptah who is south of his wall, Lord of Ankhtawy, who fashions the egg inside the belly'.

The scene which depicts a god, often Khnum/Ptah, the potter, molds the egg, ${ }^{4}$ together with the text of Philae suggest that the term in its meaning 'to form, create' is connected metaphorically with the cosmogonic of the egg.

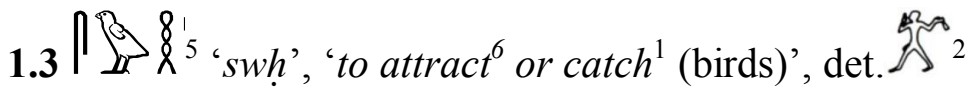

wheel on a clay egg instead of a human figure. Bénédite identified the divine figure in this scene with Khnum, while Giammaruti, and Bettles identified him with Ptah-Tatenen. The earliest attested scene of Khnum fashioning an egg at the wheel, is dated back to Hatshepsut. E. Naville, The temple of Deir el-Bahari II Plates XXV-LV, II (London, 1896), pl. 48. E. Bettles, "The divine Potters of Kellis", OLA 204 (2011): 213, fig. 13, pl. 1, 2, 13, 14, and 16. For other depictions of Khnum or Ptah fashioning an egg on the potter's wheel, cf. D. Klotz, 'The Earliest Representation of a Potter's KickWheel in Egypt', ENiN 6 (2012): 169-176ff; Bettles, "The divine Potters of Kellis": 213, figs. 1-17; R. Holtheor, New Kingdom Pharaonic Sites: The Pottery. The Scandinavian Joint Expedition to Sudanese Nubia, 5:1 (1977), 26 (LPA 12), fig. 40; Dorman, Faces in Clay, 119.

1 Philä II, 181, 2-3. In an interesting cryptograph on a fragment of a magical stela acquired by the Bibliothèque Humaniste et Municipale at Sélestat, and dated to the New Kingdom. It depicted Ptah generating an egg. The accompanying inscription reads 'Pth hpr $\underline{d}$ s.f' 'Ptah, who developed from himself'. Cf. E. Graefe, 'Phallus und Ei: Ptah als Urgott, Das fragment einer magischen stele der Bibliothèque Humaniste et Municipale de Sélestat,' in W. Clarysse, A. Schoors, H. Willem (eds.), Egyptian Religion: The last Thousand Years, I, Studies Dedicated to the Memory of Jan Quaegebeur, OLA 84 (1998): 117-124ff, pl. I.

${ }^{2}$ Esna 320, 23: also at the Khonsu temple in Karnak, describing Amun: 'it $n t$ ' $m w t n t$ swht'. Mendel, Die kosmogonischen Inschriften, 38f, Taf. 3.

3 Bettles, "The divine Potters of Kellis": 221, fig. 13, pl. 1

4 D. Budde, Das Götterkind im Tempel, in der Stadt und im Weltgebaude, MÄS 55 (2011), 403, and 175 (footnote n. 857). So Khnum was depicted fashioning an egg on his potter's wheel; this text and other similar texts " $k m$ 3 swh.t"' describe and assert his creative attributes, and agreed that the egg was his work.

5 WB IV, 72.7; R. Hannig, Ägyptisches Wörterbuch I: Altes Reich und Erste Zwischenzeit Ägyptisches Wörterbuch I: Altes Reich und Erste Zwischenzeit. Hannig-Lexica 4; Kulturgeschichte der Antiken Welt 98. (Mainz: Philipp von Zabern, 2003), 1090. A. Moussa \& H. Altenmüller, Das Grab des Nianchchnum und Chnumhotep, AV 21 (Mainz: Philipp von Zabern, 1977), 78, Taf. 22, Abb. 9 (1 ${ }^{\text {st }}$ and $2^{\text {nd }}$ row); N. Kanawati, M. Abder-Raziq, The Teti Cemetery at Saqqara. Volume V: The tomb of Hesi. Australian Centre for Egyptology: reports 13. (Warminster: Aris \& Phillips, 1999), 34, pl. 56.

6 Hannig, Ägyptisches Wörterbuch I, 1090. It occurred from the Old Kingdom in the mastaba of Nianchchnum. PM 3:2, p. 641-4 [5, 6, 8]; A. Moussa, H. Altenmüller, Das Grab des Nianchchnum 
A verb which is attested in the meaning 'to attract, catch, collect, assemble (birds/ fowl)' from the Old Kingdom onwards. It occurs in the accompanying captions to the scenes of catching the birds. ${ }^{3}$ It is occasionally determined with the hieroglyph $\mathscr{S}^{2},{ }_{4}$ a sign that represents the birds' catcher. ${ }^{5}$ Moussa commented on its attestation in the tomb of Nianchchnum and Chnumhotep at Saqqara that the term 'swh' means 'collecting (Orioles) ${ }^{6}{ }^{6}$ In this meaning, a scene from the tomb of Hesi at Saqqara depicts hunting of the birds, ${ }^{7}$ and labeled:

$$
\begin{aligned}
& \text { 's(w)h gnw } 3 n k 3 n \text { hrj-tp nswt jmj-r wp(w)t htpt-ntr...'} \\
& \text { 'collecting numerous orioles, for the ka of the royal chamberlain, the overseer of } \\
& \text { apportionments of the god's offering ...? }
\end{aligned}
$$

Another scene, with the typical figure of the birds' catcher, appears again in the tomb of Nianchchnum and Chnumhotep. ${ }^{9}$ The accompanying caption is crashed, while only traces read '.. gnw' in the first row, and 'swh ..' in the second. Suggesting a caption similar to the aforementioned one from the tomb of Hesi: 'collecting Orioles' ${ }^{10}$ In the scene at the tomb of Hesi, the catchers are showing using their hands to push the birds

und Chnumhotep, 70, 78, Taf. 22, Abb. 9 ( $1^{\text {st }}$ and $2^{\text {nd }}$ row). It also comes with this meaning in reference to humans, or, cf. idem, 70 and 78.

1 Hannig, Ägyptisches Wörterbuch I, 1090. It occurs from the Old Kingdom in the private tombs, i.e. the mastaba of Ti. PM 3:2, p. 468-77 [5,6,9]; G. Steindorff, Das Grab des Ti. III. Veröffentlichungen der Ernst von Sieglin Expedition in Ägypten 2. (Leipzig: Hinrichs, 1917), Taf. 131; H. Wild, Le tombeau de Ti III: la chapelle (deuxième partie). Mémoires publiés par les membres de l'Institut français d'archéologie orientale 65 (3). (Le Caire: Imprimerie de l'Institut français d'Archéologie orientale. Dessins de Henri Wild, 1966), taf. 170; Verner, Khentkaus, 73, 88 [5].

2 Kanawati and Abder-Raziq, The tomb of Hesi, pl. 56.

3 I.e., in the Mastaba of Ti, Hesi, Nianchchnum, cf. below.

4 Kanawati and Abder-Raziq, The tomb of Hesi, pl. 56.

${ }^{5}$ Who is depicted in the accompanied scene itself, see: Kanawati and Abdel-Raziq, The tomb of Hesi, pl. 56.

6 Moussa and Altenmüller, Das Grab des Nianchchnum und Chnumhotep, 78. Moussa discussed other possible translations, while asserting his translation with attestations from the tombs of $\mathrm{Ti}$ and of Neferherenptah (Smith, Art and Architecture, taf. 50a). On the other hand, Hannig translated the verb in the meaning of 'catching (flies)' asserting his translation with attestations from the Old Kingdom private tombs 'see infra'. Hannig, Ägyptisches Wörterbuch I, 1090.

7 The scene is in the portico, west wall upper part, $2^{\text {nd }}$ register (right). The tomb is dated to early Sixth Dynasty. Kanawati and Abder-Raziq, The tomb of Hesi, 34, pl. 56.

8 Kanawati and Abder-Raziq, The tomb of Hesi, 34.

${ }^{9}$ Moussa and Altenmüller, Das Grab des Nianchchnum und Chnumhotep, 78, Taf. 22, Abb. 9 (1st and 2nd upper rows, northern wall of the chamber); P. Montet, Les scènes de la vie privée dans les tombeaux égyptiens de l'ancien empire (Strassburg, 1925), 262.

10 Another scene in the mastaba of $\mathrm{Ti}$, at Saqqara, depicts men catching and collecting birds into the stockade. The main scene is labeled: ' $m 33$ swh gnw irrt $k 3 t n b$ ', while the first and second rows are labeled: 'int gnw'. The sequence of this scene is damaged, but the traces of its main caption suggest being a copy of the scene of Hesi. For the scene cf., G. Steindorff, Das Grab des Ti, III, Taf.170; W. Smith, The Art and Architecture of Ancient Egypt (USA: Harmondsworth: Penguin Books. USA, 1958), Taf. 50a. 
to fly towards the net. In one hand, each man is standing rising his right hand up behind his body, and waving with a piece of cloth; while the left hand is just placed at the mouth. The catchers are waving hands and uttered, either to frighten the birds away or to push fowls to the stockade. An act that is presumed to be a sort of performance that use mimicking of bird vocalizations; thus, a phonological association with the birds' warble is assumed. Often, the catcher mimic birds' warble repeating ' $s w h$ ' to attract them. ${ }^{1}$ A homonymous relation is noticed between the pronunciation of ' $s w h$ ' and the warble of birds, ' however, it is difficult to associate such interpretation with the original meaning of the term due to the absence of direct textual occurrences.

Thus, it is suggested that the term in this context is a newly acquired meaning that is derived from 'swh, to vest, enwrap, etc.' This comes in a metaphorical association since meanings such as collecting, assembling, and calling (someone/ something) is associated with wrapping up and enveloping something. Collecting or assembling something could be by wrapping it up. It has been noted that a term can be transferred semantically from an original meaning into a newly acquired meaning, while the frequent use in the new meaning allows it to become independent and to be treated as an original. Then, other meanings might be derived from the new acquired meaning. There are examples of attestations of the term ' $s w h$ ' where other new meanings are suggested, while it assumed here that these new meanings are mostly derived from the discussed meaning. Thus, these other meanings are discussed hereafter as subordinate entries:

\subsection{1 'swh', ' 'to call (birds, (in order to gather or attract them)'}

This is an assumed meaning for the verb ' $s w h$ ', which is suggested to be derived from the warble of some sort of fowl or a bird. The earliest attestations of ' $s w h$ ', in the frequent scenes of catching birds, assert this meaning. Accordingly, it is suggested to be the origin from which its original meaning is derived. In the previous entry, the verb ' $s w h$ ' is used in the meaning of catching the birds; and it is determined with a hieroglyph represents 'the birds' catcher or caller ( 2 )'. The catcher is depicted while he performs catching the birds in the same scene. It is known that ancient Egyptians have been inspired by the surrounding environment, which is even attested in their ritual performances and myth. Egyptians are used to mimic birds' warbles as a means of gathering fowls into stockades. A tradition which is still surviving, they are used to mimic birds sounds, either in hunting trips, to collect fowls into the stockades, or to be fed. Nowadays, farmers often pronounce repeatedly the word ' $s w h$ ' to collect fowls into stockades. ${ }^{3}$ Thus, it is assumed that 'swh' might have the meaning 'to call (birds, in order to collect them)', in the accompanying captions of scenes like the scene from the tomb of Hesi.

\footnotetext{
${ }^{1}$ Otherwise, it may be even to threaten the birds by simulating the warble of a bird and warning them to a a sense of danger, causing them to fly upwards to thereby become entangled in the netting.

- The act of the fowls' catchers mimicked bird sounds inherited in some local tradition of the hunters.

2 This is a suggested meaning, however, a metathesis of ' $s w h$ ' is assumed with the verb 'shwi', in their meanings and roots, which might render these attestations to the verb shwi, see infra.

${ }^{3}$ In order to interpret its meaning, a research among aged people was carried out. Some just returned its origin to the Egyptian inherited culture, while some others assumed to be a simulation to the warble of the birds, but no certain meaning have been assured.
} 
The suggested meaning can be considered as a new acquired meaning derived from 'swh' in its meaning 'to collect, to assemble,' however, the metaphorical connection with the warble of birds is a possibility that deserves a consideration.

$$
\text { 1.3.2 } 1 \text { \& \& 'swh', 'to catch (flies), }
$$

Hannig ${ }^{2}$ listed another entry under the term 'swh', or literary the expression 'swh 'ff', in the meaning of 'catching flies' which refers to a sort of a dance or performance. Hannig listed few attestations for the term in this meaning, which includes a scene ${ }^{3}$ showing dancers captioned with 'shw 'ff' 'catching flies'. The scene depicted two men doing a sort of a ritual dance. ${ }^{4}$ It seems that the verb 'swh', in this context, has a different meaning and probably a different root. ${ }^{5}$ No other occurrence is known for the term under this meaning, and unfortunately, the accompanying caption in the two known scenes are damaged. Even the scene from the mastaba of Ptah-Hetepu has no much to tell about the series of actions/ performance of the dancers.

1.4 \& 'swh (pzn)', 'to knead or press (the pzn-bread),6

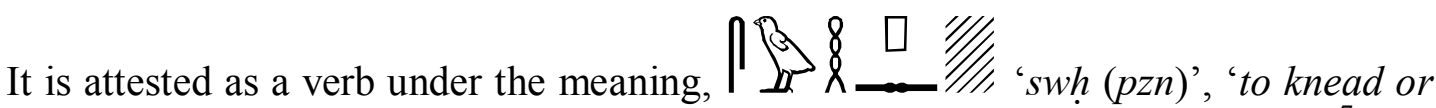
press (the pzn bread (in making bread))', or 'to form', in some other occasions. ${ }^{7}$ The term ' $s w h$ ' probably occurred in this occasion in the place of expression ' $s k r p z n$ '. ${ }^{8}$ No other known attestations of the verb under this meaning, and thus this meaning is not even proved as an alternative meaning for ' $s w h$ '. Though it is a rare use, it is suggested to be a new acquired meaning of 'swh, to form' 'see supra.'

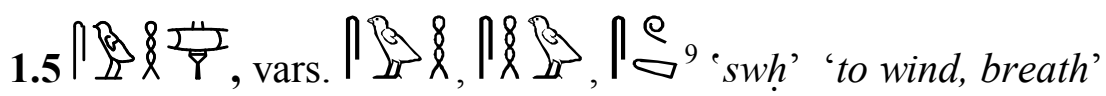

\footnotetext{
${ }^{1}$ Hannig, Ägyptisches Wörterbuch I, 1090 ('swh 'ff', Fliege fangen (eine Tanzschritt)). He listed this meaning for the term 'swh' asserted with a sole attestation from the mastaba of Ny-ankh-Pepy at Saqqara.

${ }^{2}$ Hannig, Ägyptisches Wörterbuch I, 1090.

${ }^{3}$ A scene from the mastaba of Ny-ankh-Pepy at Saqqara, Old Kingdom. The scene is damaged and the caption is unreadable. S. Hassan, Mastabas of Ny-'ankh-Pepy and Others. Edited by Zaki Iskander. Excavations at Saqqara 1937-1938 (2). (Cairo: General Organisation for Government Printing Offices, 1975), 107-108 with fig. 55.
}

${ }^{4}$ The same scene and caption occurs again in the mastaba of Ptah-Hetepu from Saqqara.PM III, 605 (Ptah-hetepu Mastaba); S. Hassan, Excavations at Saqqara, 1937-1938, II (Cairo: General Organisation for Government Printing Offices, 1975), 105-113ff, fig. 55-59, pl. LXXXIII-LXXXVI. Hannig corrected the reading of S. Hassan, and commented on the meaning of the term in this sequence is to mean 'catching flies (a dance)'. Hannig, Ägyptisches Wörterbuch I, 1090. Hannig translates it in the meaning of 'Fliegen fangen (e Tanzschritt.)'

5 A metathesis of 'swh' is assumed with the verb 'shwi, to collect; to assemble' in their meanings and roots. WB IV, 211.13-212.5; FCD 238; Urk. IV, 6,12; 649,8; 1278,2; Meeks, ALex. 77.3457.

${ }^{6}$ Hannig, Ägyptisches Wörterbuch I, 1090. Cf. PM 3:2, 344 [5.6-5.9]; Borchardt, Neuserre, 124.

${ }^{7}$ Cf., e.g. Moussa and Altenmüller, Das Grab des Nianchchnum und Chnumhotep, 70.

${ }^{8}$ Moussa and Altenmüller, Das Grab des Nianchchnum und Chnumhotep, 70, note 229.

${ }^{9}$ WB IV, 72. 9-15; FCD 217; Hannig, Grosses Handwörterbuch Ägyptisch-Deutsch, 679; idem, Ägyptisches Wörterbuch I, 1090.; Wilson, A Ptolemaic Lexikon, 812. 


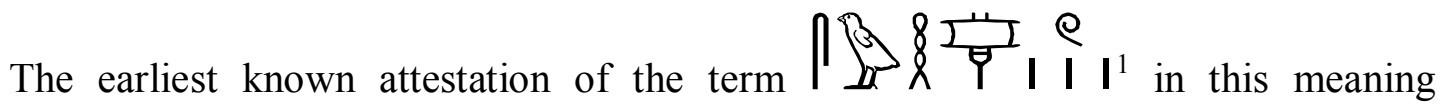
occurred on a stela from Karnak from the Twenty-second Dynasty. ${ }^{2}$ Then, it is attested frequently as a verb 'to wind, breath', and/or noun with the meaning 'air, breath, wind'; occasionally 'incense', from the Late and the Ptolemaic Periods. The term appears, in addition to other words, to serve this meaning, ${ }^{3}$ and accordingly is often determined with the proper determinative ${ }^{\text {Y. }}{ }^{4}$. From another point of view, Wilson originated the noun ' $s w h$ ' to the verb ' $i w h$ ', 5 ' to raise, lift'. The ' $s$ ' is a causative with a particular application to the wind, as the most tangible and physical signs of the air rising up the sky. ${ }^{6}$ She commented that this is a rare word attested in a few occasions which asserting asserting her opinion. ${ }^{7}$ No frequent evidence supports her view (?). In a few occasions, the term ' $s w h$ ' is used to indicate the wind, for example, its attestation in the story of Sinuhe in reference to the northern wind. ${ }^{8}$ Otherwise, it is associated with the functional functional attributes of deities connected to the wind and air. ${ }^{9}$ It is attested at the Opet temple in Karnak in a text from the region of Ptolemy VII, which reads: 'swh pw mn m (j)h,t $n b(. t)$ ' $n$ h.tw jm.f d.t' ${ }^{10}$, 'It is the breath that remains in all things, which one lives forever. ${ }^{11}$ It also occurs twice, in parallel phrases with ' $t 3 w$ ' 'wind', in the Temple of Dendera, in the meaning of 'wind, breeze,"

' $(\underline{3} w) \operatorname{pr}[\mathrm{m}$ imntt $] \check{s} w$, swh $n$ it. $<f>$ ',

'The dry (wind) from [the West], the breeze (cool wind) are to his father.'13

${ }^{1}$ G. Legrain, 'Deux steles trouvees a Kamak en fevrier 1897,' Z̈̈S 35 (1897) 16, line 32; Wilson, A Ptolemaic Lexikon, 812.

${ }^{2}$ On a stela from the region of Osorkon I, cf. S. Morenz, 'Das windbefruchtete" Welt-Ei', in S. Morenz (ed.), Aus Antike und Orient: Festschrift Wilhelm Schubart zum 75. Geburtstag (Leipzig: Otto Harrassowitz., 1950), 90f.

${ }^{3}$ Morenz, Aus Antike und Orient, 83, 93.

${ }^{4}$ Gardiner, Egyptian Grammar, 499 (P5): sail, used as ideogram or determinative in words such as 'tz3w', 'breath, wind'.

${ }^{5}$ This verb has not been listed in the entries of the dictionary of Berlin.

${ }^{6}$ Wilson, A Ptolemaic Lexikon, 812.

${ }^{7}$ Wilson, A Ptolemaic Lexikon, 812.

8 A. H. Gardiner, Notes on the story of Sinuhe (Paris: Honoré Champion 1916), 154; R.A. Caminos, Literary Fragments in the Hieratic Script, Oxford 1956, 51-52. pls. 24-25; R. Koch, Die Erzählung des Sinuhe, BiAe XVII (1990), 1-20.

${ }^{9}$ WB IV, 72.10-12; Wilson, A Ptolemaic Lexikon, 812; Morenz, Aus Antike und Orient, 83-93.

${ }^{10}$ Opet 143; De Wit, Les inscriptions du temple d'Opet à Karnak, II, Tf. 6 (above); III, 79. In another text from Opet temple, reads: 'The swd3-b3 joined him under the breath of life ( $h r$ swh $n$ ' $n h$ ), when they came'. De Wit, Opet, 183-184, 2.; De Wit, Les inscriptions du temple d'Opet à Karnak, II, Taf. 14; III, 102. WB IV, 72.13.

${ }^{11}$ A. Paulet, Leuven Online Index of Ptolemaic and Roman Hieroglyphic Texts.

12 Dendara II, 28, 3; 58,7.

${ }^{13}$ Dendara II, Traduction, 50f, $94 \mathrm{f}$. 
Apart from the interpretation of Wilson, the use of the term under this meaning is interesting. In the meaning 'to wind' which means 'to move or cause to move in a sinuous, spiral, or circular course', a metaphorical association with the term 'swh, to enwrap, envelope, circulate' is assumed. Thus, it is probably derived from this meaning, and then, it becomes an independent meaning from which the meaning of 'to breathe, and air' are gained later based on the metaphor of the wind. Taking in mind that wind often move or cause to move in a circular course.

1.6

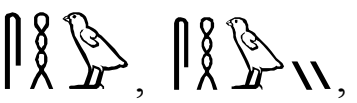<smiles>C=CC=CC1=CC=C1</smiles>
together'.

It is attested frequently as a verb from the Middle Kingdom onwards, and with other variations such as 18 e with , or $\infty_{\infty}^{2}$ It is used as a collective term for an assemblage of things, ranging from a collection of words to recruits. ${ }^{3}$ Often, the word occurs as a noun with an appropriate determinative, which defines its intended meaning.

From this term, the word $18 \|$ III shwy, is derived, in the meaning 'collection, summary, and assemblage of recruits', and its variations such as

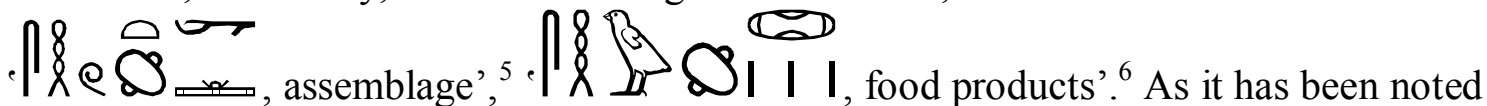
noted previously, a metathesis is assumed between ' $s w h$ ' and 'shwi' in the meanings; however, it is derived from a different terminological origin. It is noted also that 'shwi' and 'swh' might be occasionally replaced by each other, though both terms have different roots.

\section{The derived words}

2.1 'swh.t', 'egg'

'swh.t' is a female nominal construction, which is derived from 'swh, to enshroud, enwrap, wrap, envelope', 'see supra (1.1). ${ }^{7}$ It often occurs in the meaning of 'egg' and

\footnotetext{
${ }^{1}$ WB IV, 211.13-212.5; FCD 238; Hannig, Grosses Handwörterbuch, 735; Sinuhe, B130; Urk IV, 6,12; 649,8; 1278,2; Lesko, A Dictionary of Late Egyptian, II, 61-62.

${ }^{2}$ WB IV, 211.13-212.5; FCD 238; Lesko, A Dictionary of Late Egyptian, II, 61-62.

${ }^{3}$ Wilson, A Ptolemaic Lexikon, 891; Lesko, A Dictionary of Late Egyptian, II, 62.

${ }^{4}$ FCD 238.

${ }^{5}$ Lesko, A Dictionary of Late Egyptian, II, 62, and for other variations see therein.

${ }^{6}$ Wilson, A Ptolemaic Lexikon, 891, for other variation and attestations see therein.

${ }^{7}$ Osing, Die Nominalbildung des Ägyptischen, 64.
} 
often is determined with the egg sign. ${ }^{1}$ The hieroglyph egg is a pictorial sign that represents the shell of an egg, which occurs as an ideogram or a determinative, ${ }^{2}$ from the PT onward. ${ }^{3}$ The noun ' $s w h . t$ ' occurred numerous times from the PT onwards. ${ }^{4}$ Its frequent attestations reflect a wide diversity, ${ }^{5}$ with a significant presence in the mythical mythical and cosmogonic texts. It occurs with different orthographies as the following:

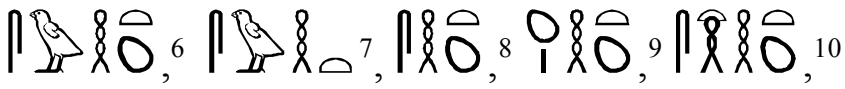

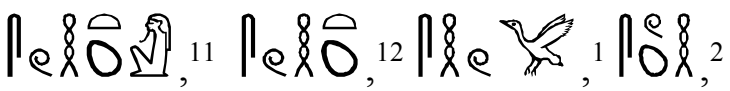

${ }^{1}$ WB IV, 73.1-18; FCD 217; LGG VI, 221; Hannig, Ägyptisches Wörterbuch I, 1090; Idem, Ägyptisches Wörterbuch II. Mittleres Reich und Zweite Zwischenzeit. Hannig-Lexica 5; Kulturgeschichte der Antiken Welt 112 (Mainz: von Zabern, 2006), 2143f; Van Der Molen, A Hieroglyphic Dictionary of Egyptian Coffin Texts, 466; Lesko, A Dictionary of Late Egyptian, II, 21; Wilson, A Ptolemaic Lexikon, $812 \mathrm{f}$.

2 M. G. Rashed, "Functions and Meanings of the Egg Determinative in the Egyptian Writing System", SHEDT 2 (2015): 62-75.

${ }^{3}$ The earliest occurrences are attested in the pyramid of Pepi I (Pyr. 1184; 1967). The egg sign was also used to give several associate phonetic values, from the Middle Kingdom into the Ptolemaic-Roman Period. Cf. Rashed, "Functions and Meanings of the Egg Determinative in the Egyptian Writing System": 62-75.

${ }^{4}$ In the pyramid of Pepi I (PT 408; 516; 669).

${ }^{5}$ Cf. R. A. Caminos, in: $L \ddot{A}$ I, col. 1186 s.v. 'Ei'; Grundriss der Medizin IV, 433f. Ebers 374; 444; 409; $539 ; 710 ; 718$. According to the medicine and drug dictionaries of Berlin, it is attested frequently in the medicaments and preparations; and in the magical Papyrus of Harris (PM EA 10042 VI, 12), cf. C. Leitz, Magical and medical papyri of the New Kingdom. Hieratic Papyri in the British Museum 7. (London: The British Museum Press, 1999), pl. 17 (12), also pl. 34 (13).

${ }^{6}$ WB IV, 73.1; Urk. IV, 248,15; 361, 14; 811, 15; 887, 1; Pyr. 1967; CT II 212b; 225b; III 156b; IV, 292b; 293b; V, 337d; VI, 343n; ODeM 1227(rt.1); Tb 71, 34 (Tb, Naville, I. LXXXIII, A.a. 13; LXXXVIII, C.a. 2); Ramesseum VI, 23, Tf. 8, Zl. 13; Tb 149 (IC3 'Th-ms; TT 353 Sn-n-mwt; PL33 $W s r-h 3 t$; PL16 Anon.; PL6 u.a. 'Imn-htp; pP4 Anon; PC2 Mjj-hr-prj; P12 Nww; PL1 Nb-snj; pP3 u.a. Nfr-wbn.f; PC1 Jwj3; PL5 Nht; PLe3 Ra; PBe1 Nht-imn) = B. Lüscher, Totenbuchtexte. Synoptische Textausgabe nach Quellen des Neuen Reiches. VI, Totenbuch Spruch, 149/150 (Basel, 2010), 135, 140f; Esna III, 320,21; J. Assmann, Sonnenhymnen in thebanischen Gräbern (1983), 290 (text 212a,10; = TT 218 (8), col. 7); Urk. VIII, 122, 1; S. Sauneron, 'Le Cerme dans les Os', BIFAO 60, 21 (Karnak: Porte d'Evergete).

7 WB IV, 73.1; Urk. IV, 949,2.

${ }^{8}$ CT IV 293b (C1N4; T2Be); VI 321j; WB IV, 73.1; PM EA 10042 VI, 12; H. O. Lange, Der Magische Papyrus Harris (Kobenhaven: Andr. Fred. Høst \& Søn, 1927), 53, Zl. 5; E. Cruz-Uribe, 'The Khonsu Cosmogony', JARCE 31 (1994), 170; Mendel, Die kosmogonischen Inschriften, Taf. 6, Zl.29, 34. And a few changes in: WB IV, 73.1; Tb 149 (pP2 Tnn3); Urk. IV, 248,15; Esna III, 320,21; FCD 217; Lesko, A Dictionary of Late Egyptian II, 21; Wilson, A Ptolemaic Lexikon, 812.

9 WB IV. 73. 2. From the Ptolemaic-Roman Period.

${ }^{10}$ WB IV. 73.2. From the Ptolemaic-Roman Period; Mendel, Die kosmogonischen Inschriften, Taf. 3 , $\mathrm{Zl} .11$; 4, Zl.16; 6, Zl.28.

11 S. Rate, Le Papyrus de Neferoubenef (Louvre III 93), BDE 43 (Paris 1968): Taf. 14 (= Tb 42 (Nfrwbn.f,Tf. 14. Zl. 444). It indicates here a divine personification as a nisbe for 'who is inside the egg.'

12 PM EA 10059 IX, 13 = Leitz, Magical and Medical Papyri, P1. 34 (13); Grundriss der Medizin IV, 433; P. Berlin P. 3027 (IV, 10); N. Yamazaki, Zaubersprücher für Mutter und Kind: Papyrus Berlin 3027. Achet 2. (Berlin: Achet Verlag, 2003), 10; Tb 149 (Pw1, s-n-Wsrt, Vienna) = B. Lüscher, 


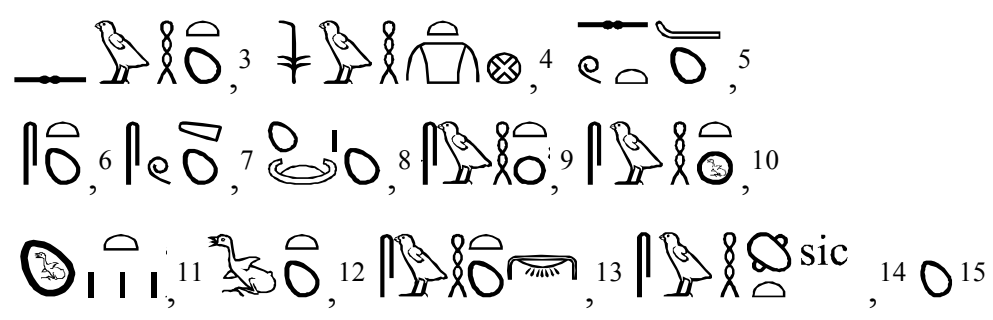

According to its numerous attestations, one can note that 'swh.t' refers often to an egg of a bird, a frog, and/or a serpent, otherwise into one of its acquired meanings which express its symbolical significance and metaphor. The egg is a metaphor for 'the primeval egg, the primeval cosmos', 'mother's womb', 'sun disk', 'offspring' because of its mythical significance and cosmogonic. In the contrast of the entries $(2.2,2.3,2.4$, 2.5 ), the following meanings, are not derived from the term ' $s w h$ ', but definitely are new meanings for the noun 'swh.t, egg' in metaphorical associations. Meanwhile the metaphoric significance has continued in the Arabic language and in particular in the Egyptian delicate. Compare for instance its Arabic equivalences (e.g. dahia and dahroug).

Totenbuchtexte. VI, Totenbuch Spruch 149/150, 140; Ebers 710; 718; Hannig, Grosses Handwörterbuch Ägyptisch-Deutsch, 680.

1 Hannig, Grosses Handwörterbuch Ägyptisch-Deutsch, 680.

2 PBrooklyn 47.218.50, VII,2; Edfou IV, 26,6; Wilson, A Ptolemaic Lexikon, 812.

${ }^{3}$ Tb 149 (PC4 Imn-htp; Pc3 u.a. Imn-htp) = B. Lüscher, Totenbuchtexte. VI, Totenbuch Spruch 149/150, 140f; Wilson, A Ptolemaic Lexikon, 812; Edfou I, 313, 14; Wilson, A Ptolemaic Lexikon, 812f; The

signs $\smile$ 'tusk of elephant' and $\square$ 'tongue of land' gave the phonetic ' $h$ ' in the Ptolemaic-Roman Period; Edfou IV, 110, 17. It occurs in the texts of Edfu temple indicating a protective amulet for Nephthys and Isis.

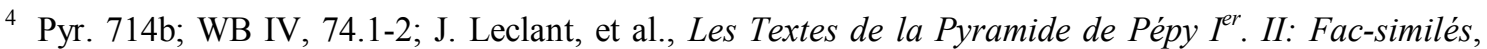
MIFAO 118/2 (2010) : pl. 9 (P/A/E), col. 17.

5 Esna III, 321, 23.

${ }^{6}$ Assmann, Sonnenhymnen in thebanischen Gräbern, 241(text 173,32 = (TT 183 (8)) col. 11)).

${ }^{7}$ Edfou V, 85, 11; 144, 16 ; 185,1; Philä II, 181.3 ; 11, 10; Daumas, Mammisis de Dendara, 126, 15.

8 Esna III, 63,3; 381,6. The sign $\circlearrowright$, 'fisherman's boat', is a semi-ideography sign in 'wh" 'fisherman, which is used as a phonetic sign. Gardiner, Egyptian Grammar, 499 (P4).

Pyr. 1967; 1968d (crushed); 1969c. Also, cf. FEPT Supplements, 50 (1967; 1968d; 1969c). ${ }^{9}$

${ }^{10}$ PT 669 (Pepi I, nr. 1049 (P/A/N 63)); CT I 176k (B13C ${ }^{\text {b }}$ plural); II, 3f(G1T). For the determinative of 'an egg with the young chicken inside,' cf. M. G. Rashed, 'The significance of the hieroglyph [the egg sign with the bird inside]', MKS I (2015): 309-32; CT III 156b; VII, 147a; $198 \mathrm{f}$ (P. Gard. II).

11 CT I, 167f (B12C $; C^{\text {b }}$ B12C ; B13C ; B16C; B20C).

12 CT III, 156b (G1T; A1C). Probably, a miswriting influenced with the word ' $t 3$ ' 'fledgling' in the preceding passage.

13 CT IV, 292b (B8C $\left.{ }^{\mathrm{a}}\right)$.

${ }^{14}$ CT II 3f (B1P); G. Lefebvre, Le Tombeau de Petosiris, II: Le Textes, 38, nr. 62, Line. 5.

15 Pyr. 1184b; For This variation in the Pyramide Textes of Pepi I, cf. Leclant, et al., Les Textes de la Pyramide de Pépy I ${ }^{\text {er }}$.II: Facsimilés, pl. XVI (P/C ant/W, col. 8); Urk. IV, 276, 1; Esna, 225,18. 


\subsection{1 'swh.t' 'son, offspring'}

The egg sign occurs in rebus as a substituted for ' $s 3$, son' 1 since it is affiliated with its its Middle Kingdom hieratic writing. ${ }^{2}$ Thus, it occurs as an ideogram for 'son' from the New Kingdom. ${ }^{3}$ In the course of time, while it is often written with the pectoral egg sign, it becomes proper to be written with one of the listed above orthographies of 'swh.t'. In this use, it is equated with the meaning of son, and it becomes acceptable to read 'swh.t' in the meaning of 'offspring/ son of', for example in CT I 167e-f/176k. ${ }^{4}$ Often, it occurs in this meaning in some royal titles and epithets from the New Kingdom. ${ }^{5}$ The king occasionally describes himself as 'swh.t, egg/ son/ offspring'. Examples from the region of Hatshepsut, who is called the ' $\mathrm{egg} / \mathrm{son}$ of Amun' and 'pure egg'. ${ }^{7}$ Thutmose III is called also 'swh.t sbk.t nt hpri, the excellent egg/ son of Amun, ${ }^{8}$ while Amenhotep III, 'swh.t špst $n t n b r \underline{d} r$, the holy egg of the lord of all,', etc.

\subsection{2 'swh.t' 'mother's womb',}

It occurs frequently referring to the mother-womb frequently in the mythical, medical and magical texts from the $\mathrm{CT}^{11}$ onwards. For example, CT spell 207 reads:

'iwr.ty $R^{e} m s(w) \underline{t} n$ wi im $(y)$ swh.t.i $m s(w)$.tn wi $\operatorname{snh} n(. w)$.tn wì',

${ }^{1}$ H. W. Fairman, "An introduction to the study of Ptolemaic signs and their values", BIFAO 43 (1945): 90 f no. (n).

2 Fairman, "An introduction to the study of Ptolemaic signs and their values": 90f n. (m). Fairman commented that the subsequent introduction of ' $\mathrm{O} s 3$ ' into hieroglyphics was due to the automatic copying of a usage already consecrated by hieratic, though it is a moot point whether its hieratic origin was always born in mind.

${ }^{3}$ WB III, 408.1 - 412.2; Gardiner, Egyptian Grammar, 474; Wilson, A Ptolemaic Lexikon, 708, 780-82; H. W. Fairman, 'Notes on the Alphabetic signs employed in the Hieroglyphic inscriptions of the temple of Edfou,' ASAE 43: 228 (191), 271 (n. XLIX).

${ }^{4}$ For a new interpretation and translation of this passage asserting this meaning, cf. Rashed, 'The significance of the hieroglyph [the egg sign with the bird inside]', MKS I (2015): 317f.

${ }^{5}$ Urk. IV, 276.1; Urk. IV, 361.14.

6 Shih-Wei Hsu, 'Figurative Expressions Referring to Animals in Royal Inscriptions of the 18th Dynasty,' JEH 6 (2013): 12f.

${ }^{7}$ Urk. IV, 276.1; 361.14.

${ }^{8}$ Urk. IV, $811.15 ; 887.7$.

${ }^{9}$ Urk. IV, 1696.17.

${ }^{10}$ E.g. Leitz, Magical and Medical Papyri of the New Kingdom, pl. 17 (12), also Pl. 34 (13); M. G. Rashed, 'The egg as a metaphor for Isis: A Coffin Text Imaginary', MKS 2 (2016): 203-208; Idem, 'The significance of the hieroglyph [the egg sign with the bird inside]': 312 .

${ }^{11}$ CT Spell 148. Cf. R. O. Faulkner, "The pregnancy of Isis", JEA 54 (1968), 40ff; Rashed, MKS 2, 204, and also 203-208, other attestations and references therein.

${ }^{12}$ CT III 156a-157a. 
'The birth of Re, you shall give birth to me who I am in the womb (lit. egg); (when) you have borne me, you shall nurse me. ${ }^{11}$

The egg shares the fertile aspects of the mother-womb of giving new birth, and thus the words might refer to the mother-womb in some medical magical attestations. ${ }^{2}$ In London medical Papyrus (BM EA 10059), an incantation to prevent bleeding, which might cause miscarriage to the pregnant women, the text reads: ' ... To be wrapped, and given to a woman at her abdomen (phwy), to repel any bleeding and any infection. This means allowing the womb (lit. 'swh.t') to grow strong and not seeing dreams. This incantation is to be spoken for each individual knot." ${ }^{3}$ The text refers metaphorically to the mother-womb with the word 'swh.t'. This is a new acquired meaning because of the metaphor of the egg.

\subsection{3 'swh.t' 'sun disk',}

The egg and the sun disk are mapped metaphorically into each other. The egg is interpreted as Ur-substance for the sun disk. Accordingly, the sun god is frequently emerging from the sun disk or the egg, from the CT onwards. This metaphor occurs for instance in CT II 44d; $;^{5}$ III $156 \mathrm{~b}$ and Tb $17 ;^{6}$ and in the final hour of LdN and the first hour of LdJ. ${ }^{7}$ The daily sunrise is a simulation in which the cycle of the sun god emerging from his egg/ disk is repeated. The sun god emerges from his egg and metaphorically in his disk. By other means, the daily rises of the sun disk. In this sense, CT II 44d reads:

'ps d.f wbn.f prr.f m swh.t.f msw.t ntr m prt,'

'when he shines, when he rises, he comes out of his egg, which is giving birth to the sun at sunrise. ${ }^{8}$

The same theme continued in $\mathrm{BD} 17:$ 'Re who is in his egg, who is shining in his disk, and rises from his horizon. ${ }^{99}$ The final hour of $\mathrm{LdN}$ and the first hour of LdJ are

\footnotetext{
${ }^{1}$ For other translations cf. FECT I, 168; C. Carrier, Textes des Sarcophagues, I, 506f; Willems, The Coffin of Heqata, $457 \mathrm{ff}$.

${ }^{2}$ Leitz, Magical and Medical Papyri of the New Kingdom, pl. 17 (12), also Pl. 34 (13); the magical papyrus Harris (BM EA 10042 VI, 12.

${ }^{3}$ Leitz, Magical and Medical Papyri of the New Kingdom, pl. 34 (13).

${ }^{4}$ Rashed, 'The significance of the hieroglyph [the egg sign with the bird inside]': 312f, 319f; Bickel, $O B O$ 134, 238-240; O. Goldwasser, 'Itn - The 'Golden Egg', CT IV 292-b-c [B9Ca])', in Van Dijk (ed.), Essays in Honour of Herman Te Velde, Egyptological Memoirs 1. (Groningen: Styx, 1997), 7984.

${ }^{5}$ See also, CT IV 292b-c; VI 323g; VI 434m-i.

${ }^{6}$ Urk. VI 55.1; 56.1.

7 A. Piankoff, The Tomb of Ramesses VI, vol. I: Texts (1954) 389 and fig. 130; M. Müller-Roth, Buch vom Tage, OBO 236 (2008), 70ff, Abb. 13 and Taf. I, XVII, XXII and XXIII. Cf. Rashed, 'The significance of the hieroglyph [the egg sign with the bird inside]': 312f, 319ff.

${ }^{8}$ J. Zandee, 'Sargtexte, Spruch 81', Z̈̈S 101 (1974): 80.

${ }^{9} \mathrm{~Tb}$ (Hornung) 17,209-211.
} 
concerned with the 'sunrise,' the rejuvenation of the sun god in his nightly and daily journeys. The sun god is represented inside his disk inside the goddess-womb, while the texts refer to the birth of the god from his egg/disk. ${ }^{1}$ It may be concluded that the sun god is inside, and emerges from, the egg and that he shines in the egg disk. Thus, the egg has been associated metaphorically and equated with the sun, sun disk, and sun god.

\subsection{4 'swh.t' 'the primeval cosmos',}

The cosmogonic of the egg is attested as early as the CT, and it is continued until the Graeco-Roman Period. The egg has been served as a metaphor for the primeval ocean/ cosmos. ${ }^{2}$ Thus, the word 'swh.t' occurs frequently in the cosmogonic texts in reference to the primeval ocean or cosmos. ${ }^{3}$ In the Biography of Petosiris, from the Twenty-Sixth Dynasty, the texts describe the creation of universe/ cosmos from the primeval egg in a metaphor to the pre-creation substance, the primeval ocean/ cosmos, and from which the creator emerges. ${ }^{4}$ In the same context on the Bark Chapel at the Temple of Khonsu at Karnak, the text above Ptah and the Ogdoad reads (Ptah): 'He ejaculated at this place in the lake, he who created in Tjenenet, so that it (the egg) might be engendered through him like those (things), which come into existence in its (the egg) name of 'seed' so that he might bring forth the egg so that the Ogdoad might come into existence out of it (the

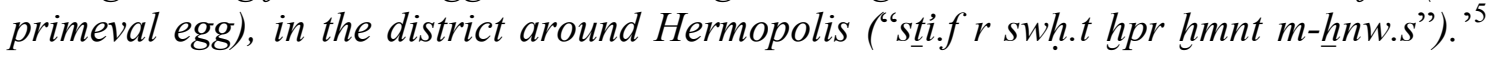
This cosmogonic text describes the creation of the universe, and the emerging of the creator god, where the egg refers to the seeds of creatures and into the cosmos. ${ }^{6}$

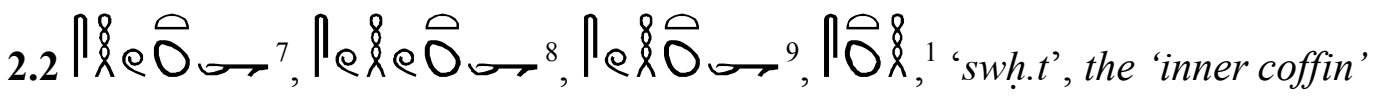

${ }^{1}$ For the interpretation of this scene, cf. Rashed, 'The significance of the hieroglyph [the egg sign with the bird inside]': 312f, 319-22, and the attestations therein.

${ }^{2}$ Cf. Morenz, Aus Antike und Orient, 73f; J. P. Allen, Genesis in Egypt: the Philosophy of Ancient Egyptian Creation Accounts. Yale Egyptological Studies 2. (New Haven: Yale Egyptological Seminar, Department of Near Eastern Languages and Civilizations, 1988), 8ff, 13ff; G. Lefebvre, 'L'Oeuf divin d'Hermopolis', ASAE 23 (1923), 65ff; G. Roeder, Hermopolis 1929 - 1939: Ausgrabungen der Deutschen Hermopolis-Expedition in Hermopolis, Ober-Ägypten (Hildesheim, 1959), 186 (ss.44c); S. Morenz, Ägyptische Religion, Die Religionen der Menschheit 8 (1960), $187 \mathrm{f}$.

${ }^{3}$ For more relevant attestations, cf. S. Bickel, La Cosmogonie égyptienne. Avant le Nouvel Empire, OBO 134 (Freiburg (Schweiz); Göttingen: Universitätsverlag; Vandenhoeck \& Ruprecht, 1994): 234-241ff; Mendel, Die kosmogonischen Inschriften, $44 \mathrm{ff}$.

${ }^{4}$ G. Lefebvre, Le Tombeau de Petosiris, II: Le Textes (Le Caire: IFAO Press, 1923), 38f, nrs. 62 and 81; Idem, ASAE 23, 65ff; Roeder, Hermopolis, 186 (ss.44). Again in another hymn addressing Amun-Re at the temple of Hibis. K. Sethe, Amun und die acht Urgötter von Hermopolis. eine Untersuchung über Ursprung und Wesen des ägyptischen Götterkönigs. Abhandlungen der Preußischen Akademie der Wissenschaften zu Berlin 1929 (4). (Berlin: Verlag der Akademie der Wissenschaften; Walter de Gruyter, 1929), 79f (ss. 157); N. de Davies, The temple of Hibis in el Khārgeh Oasis. Part III: The decoration. Edited by Ludlow S. Bull and Lindsley F. Hall. Publications of the Metropolitan Museum of Art Egyptian Expedition 17. (New York: Metropolitan Museum of Art, 1953), 25, pl. 33 (ii).

${ }^{5}$ E. Cruz-Uribe, 'The Khonsu Cosmogony,' JARCE 31 (1994): 173 and pls. 34-5.

${ }^{6}$ For more attestations, cf. Mendel, Die kosmogonischen Inschriften, 44ff.

${ }^{7}$ PBerlin 12343, verso, 6 (= Hieratische Papyrus aus den königlichen Museum zu Berlin III, 1911, 50-51, 51, pl. XXXIVa and XXXIV); HO, I, pl. LX.5,3.

${ }^{8} \mathrm{HO}, \mathrm{I}, \mathrm{pl} . \mathrm{XXI} .1$ ver.4.

${ }^{9} \mathrm{WB}$ IV, 74. 4. 
A noun which is derived from the term 'swh, to enshroud, enwrap, wrap'. In these particular cases, 'swh.t' means 'inner coffin,' also 'mummy mask or mummy case,' a translation that is understood from the context of the texts. In this meaning, it is often

determined with the sign , together with the egg sign. Lapp ${ }^{3}$ commented on the occurrences of the egg sign as an ideogram for the inner coffin (the anthropoid mummy case)' in connection with the Hermopolitan view of creation and the cosmogonic aspect of the egg.

The attestations of 'swh.t', with this meaning, mostly occur in the prices of commodities from the Ramesside Period. Invariably, it indicates 'the innermost coffin,' in the sense of distinguishing between the outer coffin, coffin and innermost coffin. This distinction was made by using specific terms for each in the price lists, where they mostly occur together on the same ostracon texts. ${ }^{4}$ According to the examples presented in the study of Janssen, it has not been attested in the meaning of 'the innermost coffin' before the middle of the Nineteenth Dynasty. ${ }^{5}$ At the time, it occurs on eight ostraca giving the cost, accompanied as far as possible, by the price of the ' $w t^{\prime}$ ' the anthropoid coffin' belonging to the same coffin set. ${ }^{6}$ However, the commodity prices ostraca distinguished between the various coffin types by using the given names, but nowhere does it explain using special words for those types.

It is noted that the egg could occur in resemblance with the coffin, mummy wrappings since the egg is a metaphor for birth and rebirth. The coffin and the egg share similar aspects; the coffin encloses the body (physically) and ensures the rebirth of the dead (symbolically). Thus, the coffin symbolically is associated with the cosmogony of the egg. ${ }^{7}$ In several occasions, religious texts describe the rebirth of the dead person as who comes out forth from his coffin. Though, the metaphorical connection is proved between the coffin/ mummy wrappings and the egg, which even the scribe insists to

${ }^{1} \mathrm{HO}, \mathrm{I}$, pl. LIX.1 ver.1, and 2.

${ }^{2}$ WB IV, 74.4; Hannig, Grosses Handwörterbuch Ägyptisch-Deutsch, 680; Wilson, A Ptolemaic Lexikon, 812; FCD 217; Lesko, A dictionary of Late Egyptian, II, 21. According to Gardiner, in this context, it refers to the meaning of 'Coffin', 'mummy case.' A. Gardiner, "A Lawsuit arising from the Purchase of Two Slaves", JEA 21 (1935):143 (n. 12).

${ }^{3}$ G. Lapp in: $L \ddot{A} \mathrm{~V}$, col. 461 s.v. 'Sarg'.

${ }^{4}$ J. Janssen, Commodity Prices from the Ramessid Period. an economic study of the village of necropolis workmen at Thebes. (Leiden: E. J. Brill, 1975), 213f, 235f. Different names were used to distinguish between the inner and outer coffins, and between the different types, e.g.: ' $w$ t, anthropoid coffin', 'swht, inner coffin' 'mn-'nhh, outermost anthropoid coffin', otherwise called 'wt '3' and 'd $d b 3 t$, sarcophagus'. Janssen discussed these terms together with their relevant attestations, cf. Janssen, Commodity Prices, $209 \mathrm{ff}$.

5 Janssen, Commodity Prices, 215.

${ }^{6}$ Janssen, Commodity Prices, 235f and Table XXXIV, (i.e. in HO, I, 59,1. vs.1 and 2; 21,1.vs.4;O. Berlin 12 405,4; and 14 366, 3-4; O. Turin 9599, 3-4 and 8); and for its decoration price attestations, Table XXXV (i.e. HO, I, 60,5,3; O Berlin 12 343, 5 and 6).

7 In this context, Manassa in her discussion of the sarcophagi decorations and types, noted: 'the sarcophagus itself may serve as a replacement for the egg of Sokar or the entire Land of Sokar, one of the most important elements in the Fourth and Fifth Hours of Amduat, possibly leading to the omission of those hours on several of the Late Period sarcophagi.' C. Manassa, The late Egyptian underworld: sarcophagi and related texts from the Nectanebid period. Part 1: sarcophagi and texts. Ägypten und Altes Testament 72 (Wiesbaden: Harrassowitz, 2007), 443. 
ensure through the determinative of the egg sign, but the word in this meaning is derived from 'swh', 'to vest, enwrap, wrap', the same term from 'swh, egg' is derived. The coffin envelopes dead person who is wrapped inside, in a resemblance with the egg and the young chicken inside.

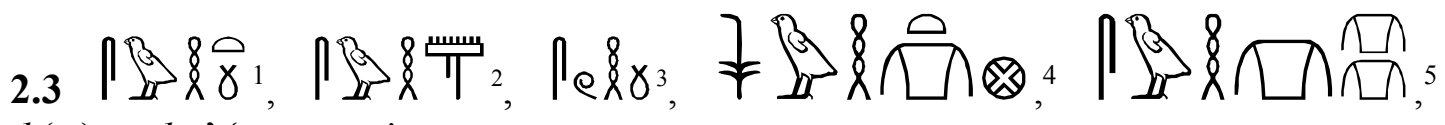
'swh(w), swh.t' 'garment'

A word that occurs from the PT onwards, with the meaning of 'garment,' 'a skirt or shirt of a particular shape, ${ }^{6}$ such as a loincloth, mantle, apron or shawl. It is derived from 'swh', 'to vest (oneself),' 'see supra'. Jequier ${ }^{7}$ mentioned it as a name of a coat in the Middle Kingdom. Janssen ${ }^{8}$ assumed that it indicates to some kind of 'shawl,' which is supported by its attestation in PHarris I, 14b, 2, and in graffito 1282, 17. ' A variation of the word occurs as early as the PT, in which it probably occurs with two subdivided meanings 'garment (Pyr. 714b), and wrappings (Pyr. 1416a)'. In the PT 563, the text reads:

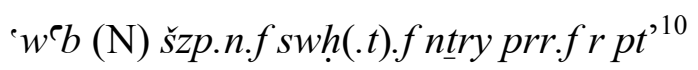

'Pepi is pure. he has taken his golden garment. (I) the sky.'11

Also, in a version of Pyr. 714b (PT 400) in the pyramid of Pepi, which reads: 'Come, give Teti birth. ...., and give birth to him who is in the egg'. ${ }^{12}$ It occurs again in the Book of the dead, BD 172: 'May you have a garment of the best linen (šzp.k swh $n$ šs tpy). ${ }^{13}$ It is also attested in the hieratic PCairo 65739, 6 with the meaning of 'shroud': '1 skirt (shawl) of upper Egypt cloth, makes five kites of silver.' 14

\footnotetext{
${ }^{1}$ PCairo 65739,6 (dated to Ramsesses II) ; FCD 217; CT VII, 201g; Gardiner, "A Lawsuit arising from the Purchase of Two Slaves": 142, 143 (n.12), and pl. XIII-XIV.

2 WB IV, 72,3; CT III 64d; V 26c; FCD 217; Hannig, Grosses Handwörterbuch Ägyptisch-Deutsch, 680; Van der Molen, A Hieroglyphic Dictionary of Egyptian Coffin Texts, 465.

${ }^{3}$ Lesko, A dictionary of Late Egyptian, II , 21.

${ }^{4}$ Pyr. 714b; WB IV, 74.1-2; Leclant, et al., Les Textes de la Pyramide de Pépy Ir. II: Facsimilés, pl. 9 (P/A/E), col. 17.

${ }^{5}$ Pyr. 1416a.

6 WB IV, 72,3; FCD 217; Hannig, Grosses Handwörterbuch Ägyptisch-Deutsch, 680; Van der Molen, A Hieroglyphic Dictionary of Egyptian Coffin Texts, 465.

${ }^{7}$ G. Jéquier, Les frises d'objets, MIFAO 47 (Le Caire, 1921) $24 \mathrm{f}$.

${ }^{8}$ Janssen, Commodity Prices, 290.

${ }^{9}$ Černy, Graffiti, pl. 45.

${ }^{10}$ Pyr.1416a-b.

${ }^{11}$ FEPT I, 219. Compare also with: Pyr. 533b; cf. J.P. Allen, The Ancient Egyptian Pyramid Texts. Edited by Peter Der Manuelian. Writings from the Ancient World 23. ( Atlanta; Leiden: Society of Biblical Literature; Brill, 2005), P 351; P 501, P 559; M 340. Another attestation in PT 412 (Pyr. 726a); 'The mourners call to you. The imy hnt priests are vested for you (dsw n.k smn.tt swh n.k imi-hnt)'. FEPT I, 135.

12 Allen, The Ancient Egyptian Pyramid Texts, 93 (T 285), 142 (P 372).

${ }^{13}$ pLondon BM 9900 (pNebseni) (1), Tb 172.

${ }^{14}$ Gardiner, "A Lawsuit arising from the Purchase of Two Slaves": 142, 143 (n.12) and pl. XIII-XIV.
} 
In the PT 400 in the pyramid of Pepi, the word occurs with the form: $\neq$ क 810 1 'swh.t' in which it is determined with ties', likewise PT 563 (Pyr. 1416a). In the case of Pyr. 714b, an alternative translation is suggested, and which reads:

'Come, give Pepi birth. ...., and give birth to him who is in his wrappings'.

Here, both meanings are meant, the king is wrapped laying in his egg waiting for his emerging/ rebirth. Thus, the determinative gives a new acquired meaning to the noun 'swh.t', which mostly meant in the context. It refers to the dead king inside his wrappings. This meaning can be also asserted by the aforementioned attestations of the term 'swh' on the Ramesside ostracon, which reads: '. $t$-swh $m$ 3dmj', 'The limbs are covered with red linen. ${ }^{3}$ On one hand, the word has metaphorically gained this meaning meaning which is derived from 'swh, to dress, enwrap', in which the dead king is firmly wrapped with linen. On the other hand, the determinative uncovers a metaphorical resemblance with the egg. The dead king is covered, firmly wrapped up and enveloped like the embryo inside an egg. It has been noted that the egg has also the symbolic significance of 'a vestment, or wrapping' since it envelopes the embryo, and symbolically for the dead which may be confirmed as early as the PT 400 . The funeral and religious attestations probably suggest such a metaphorical association, although, the word in the meaning of 'a garment, or wrappings' is derived from the term 'swh, to vest'.

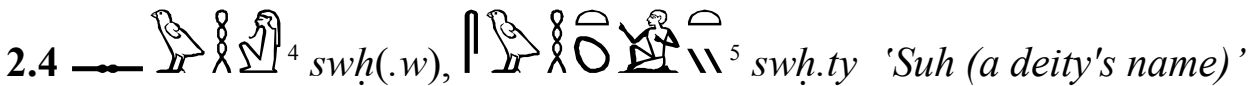

Two different divine nouns occur in religious texts. Due to the rare attestations, it is hard to ensure from which term, each of both nouns is derived.

The first noun, 'swh(.w)', is a masculine noun, probably, refers to a divinity called Suh 'swh(.w)'. The name is attested first in the CT, and then in the LdN from the New Kingdom. It has been identified with his depiction as a standing mummiform god in the LdN. ${ }^{6}$ Although the CT spell introduces this divine in a spell addressing serpents, whom whom the deceased is calling among other deities, his attributes are not known. CT VII, 97d reads: ' $i$ swh(.w) iw. n.k 3 r $r$ išs.t' 'O, Suh (swh.w). For whose cause and against whom you have come." 7 This is a magical spell against serpents in which this divinity plays a negative role. Perhaps, a divine serpent of those who are mentioned on several occasions in the CT. The meaning of his name is interesting. It probably means the '(en)shrouded one," a name which is derived from 'swh', 'to wrap up (oneself),

\footnotetext{
1 WB IV, 74.1-2; Leclant, et al., Les Textes de la Pyramide de Pépy $I^{e r}$. II: Fac-similés, pl. 9 (P/A/E), col. col. 17.

2 It often occurs as an Ideogram for ' $j$ $3 w$, interpreter'. Allen, Middle Egyptian, 443 (S 25).

${ }^{3}$ Fischer-Elfert, Literarische Ostraka, 42 (n.49).

4 CT VII, 97d; Van der Molen, A Hieroglyphic Dictionary of Egyptian Coffin Texts, 465; LGG VI, 220.

5 pLondon BM EA 10477 (pNu), Tb 042 (line 26) = G. Lapp, The Papyrus of Nu (BM EA 10477), Catalogue of Books of the Dead in the British Museum I (London: the British Museum Press, 1997), pl. 16, line 26.

6 LdN II: Copie Synoptique, 44 (line, C III); LdN, I: Traduction et commentaire, 14.

7 FECT II, 49.

8 Meeks, ALex. 78.3401. In the LdJ, the sun god is depicted in his disk/ egg enveloped by the coiled serpent Mehen 'the Enshroud one'. Piankoff, The Tomb of Ramesses VI, I, 389 and figs 130; MüllerRoth, Buch vom Tage, $80 \mathrm{ff}$. Mehen is an immense coiled serpent who stands on the night bark of Ra
} 
enwrap, envelope'. ${ }^{1}$ A serpent can enwrap or enshroud in a circle around his body, and thus the divine name is probably derived in a metaphor from 'swh, to enshroud, enwrap, envelope'.

The second is a divine name which is attested in the PLondon BM EA $10477(\mathrm{PNu})$, a version of BD 42 from the New Kingdom. The spell mentions a divine personification called 'swh.ty', which is probably a nisba from the noun 'swh.t'. The name occurs in reference to 'swh.t, egg' or the enshroud one inside the egg 'imy swh.t'. The spell of $\mathrm{PNu}$, reads:

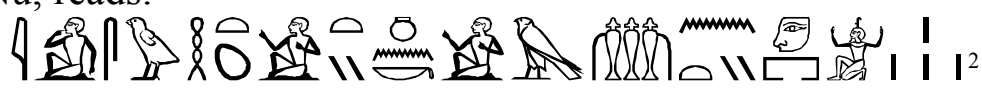

'i swh.ty ink Hr.w hnty hh.w', 'O swh.ty (the enshrouded one), I am Horus, (who is) at the front of the million ones.'

The BD 42 reads ' $O$ thou of the egg, thou of the egg, I have given the life through them' ${ }^{4}$ The speech is addressed to the egg, and metaphorically to 'the one who is inside the egg'. The $\mathrm{PNu}$ version of BD 42 presents a personification of the God who is inside his egg 'the enshrouded one'. This noun has only one occurrence which is not enough to give a quite clear explanation, but the other versions of the spell assert that this name is derived from the word swh.t-egg, and refers metaphorically to the one who is inside his egg, as it meant in the context of the spell. However, it might infer that the word swhty might refer to the diseased inside the coffin; and thus it recalls the metaphoric use and meaning of the aforementioned word $s w h t$ (coffin).

\subsection{P \& 8 \& swh, 'a "a personal name'}

A masculine noun refers to a personal name. It is attested on a tombstone dated to the Middle Kingdom at Louvre Museum. ${ }^{6}$ It is determined with the egg sign and is associated phonologically suggesting a relation with eggs or the markets(?). It is suggested that the name refers to either the seller, collector, or dealer of eggs. Due to the absence of any other attestations and any title that refers to the eggs' sellers and market, ${ }^{7}$ thus it is difficult to prove whether it is a nisba from the noun 'swh.t' for egg or is derived from 'swh'.

\section{Conclusion}

Through studying the term 'swh', the article presents a significant example of Egyptian terms which may have multiple meanings and problematic roots. The diversity

to guide the passage of the sun god in his netherworld journey. P. A. Piccione, 'Mehen, Mysteries, and Resurrection from the Coiled Serpent,' JARCE 27 (1990): 43ff; LGG III, 383-384b (23).

1 LdN I, 143 (and footnote n. 718); LGG VI, 220. Perhaps, a masculine nominal building derived from 'swh' 'to enshroud'; see, Osing, Die Nominalbildung des Ägyptischen. Textband, 64.

2 pLondon BM EA 10477 (pNu), Tb 42 (line 26).

3 Cf. the Online Internet Thesaurus (TLA): B. Backes, Totenbuch-Projekt, Ägyptologisches Seminar der Universität Bonn.

${ }^{4} \mathrm{~Tb}$ (Hornung), 42, 49-50; Tb (Allen) 42,4. Compare similar attestations, pTurin 1791, Tb 042 (line 13 and 21).

${ }^{5}$ RPN I 302.26.

${ }^{6}$ Louvre C99.

${ }^{7}$ During the Late Roman Period, governmental restrictions were imposed on Egyptian egg dealers. a text reads: "I acknowledge that I am to carry on the retailing of eggs in the market-place publicly, for the supply in retail of the said city [Oxyrhnchus] every day without intermission, and that it shall not be lawful for me in the future to sell secretly or in house." W.J. Darby, Paul Ghalioungui, and Louis Grivetti, Food: the gift of Osiris, I, (London; New York; San Francisco: Academic Press, 1977), 331. 
of the attestations of its different acquired meanings and derivations expressing the flexibility of the Egyptian Language in using metaphorical associations to produce new meanings and words. On the other hand, it also expresses how the Egyptian language had been developed in the course of time "use and practice". Often, terminological studies might express certain phoneme, phonological, lexical, graphical, and morphological aspects of the language. The term 'swh' exemplifies some of these aspects in the Egyptian Language. Its acquired meanings are metaphorically associated with the same root, as discussed. It is noted also that metathesis can cause also confusion between words with similar etymology but have a different terminological origin. A confusion which occurs due to the metathesis between 'swh' and 'shwi'; and which even causes that 'swh' and 'shwi' has been occasionally replaced each other by the fault.

It is assumed that new meaning of a term can be used later independently as roots, while other new meanings are acquired in a direct association with these new independent meanings. Compare for instance the aforementioned use of ' $s w h$ ' in the meaning of 'to create, form,' and 'to catch flies'. In addition, new words appear in use in the course of time that are derived from the original term; while some others are derived from other derived/ acquired meanings, and not from the origin. In the case of the term 'swh', it presents some significant examples. For example, the noun 'swh.t, egg' derived from the term 'swh, to enshroud, vest', while the noun 'swh.t' itself acquires other new meanings in the course of time and practice, which are listed as subordinate meanings. These words include 'son, mother-womb, the cosmos, etc.,' which have no direct association with the term ' $s w h$ ' but are associated with the egg and its metaphor. On the other hand, other noun derived from the root 'swh', e.g., 'inner coffin/ mummy wrappings, garment/ vest/ wrappings'. While some nouns, which are used frequently, are derived from one of its later acquired meanings, e.g., 'swh, to knead or press,' which is assumed to be derived from 'swh, to form, create'. The theological and metaphorical connection between the egg and the coffin are among the widest and the most interesting. In one hand, Egyptians captured the imagery of the egg as a source of life enshroud the new life/ new born inside it, and the coffin/ land which enshrouds the dead body inside it as her child. An oriental concept that has been rooted not just in ancient Egypt but also extended into the entire ancient world. Thus, the term ' $s w h$ ' is used frequently to express this metaphor in the cosmogonic, funeral and literature contexts. These metaphoric connections are discussed by Susan Bickel, Dagmar Budde and is the subject of a forthcoming article of the author. Finally, one can note that the term ' $s w h$ ' exemplifies terms that transferred semantically from original meaning into newly acquired meanings that become independents and treated as new roots. In this sequence, it probably creates a new word family.

\section{Bibliography}

- C. Leitz, Magical and medical papyri of the New Kingdom. Hieratic Papyri in the British Museum 7. (London: The British Museum Press, 1999). 
- D. Mendel, Die kosmogonischen Inschriften in der Barkenkapelle des Chonstempels von Karnak, MRÉ 9 (Turnhout: Brepols. 2003).

- D. Klotz, 'The Earliest Representation of a Potter's Kick-Wheel in Egypt', ENiN 6 (2012).

- D. Budde, Das Götterkind im Tempel, in der Stadt und im Weltgebaude, MÄS 55 (2011).

- E. Edel, "Beiträge zu den Inschriften des Mittleren Reiches in den Gräbern der Qubbet el Hawa," MÄS 25 (1971).

- E. Naville, The temple of Deir el-Bahari II Plates XXV-LV, II (London, 1896).

- E. Bettles, "The divine Potters of Kellis", OLA 204 (2011).

- J. Osing, Die Nominalbildung des Ägyptischen. Textband. Deutsches Archäologisches Institut, Abteilung Kairo 3 (Mainz: Philipp von Zabern, 1976).

- H.W. Fischer-Elfert, Literarische Ostraka der Ramessidenzeit in Übersetzung. Kleine ägyptische Texte [9]. (Wiesbaden: Harrassowitz, 1986).

- Hannig, Grosses Handwörterbuch Ägyptisch-Deutsch, 680; R. Van Der Molen, A Hieroglyphic Dictionary of Egyptian Coffin Texts, Probleme der Ägyptologie 15. (Leiden: Brill, 2000).

- H. Wild, Le tombeau de Ti III: la chapelle (deuxième partie). Mémoires publiés par les membres de l'Institut français d'archéologie orientale 65 (3). (Le Caire: Imprimerie de l'Institut français d'Archéologie orientale. Dessins de Henri Wild, 1966).

- Hannig, Ägyptisches Wörterbuch II. Mittleres Reich und Zweite Zwischenzeit. HannigLexica 5; Kulturgeschichte der Antiken Welt 112 (Mainz: von Zabern, 2006).

- H. L. Lesko, A Dictionary of Late Egyptian, II (USA: Providence, RI: Scribe Publications, 2002).

- G. Bénédite, Le Temple de Philä, MMAF 13/2 (Le Caire: IFAO, 1895).

- G. Posener, Catalogue des ostraca hiératiques littéraires de Deir el Médineh. Tome III (fasc. 3): nos. 1607-1675. Documents de fouilles de l'Institut français d'archéologie orientale 20 (3). (Le Caire: Institut français d'Archéologie orientale, 1938).

- Gardiner, Egyptian Grammar (Oxford: Oxford University Press, 1950).

- G. Lapp, The Papyrus of Nu (BM EA 10477), Catalogue of Books of the Dead in the British Museum I (London: the British Museum Press, 1997).

- G. Steindorff, Das Grab des Ti. III. Veröffentlichungen der Ernst von Sieglin Expedition in Ägypten 2. (Leipzig: Hinrichs, 1917).

- J.P. Allen, Middle Egyptian. an introduction to the language and culture of hieroglyphs, 2nd, revised ed. (Cambridge: Cambridge University Press, 2010).

- M.G. Rashed, "The Four Primeval Elements of Creation according to the Philosophy of Hermopolis: A new Interpretation of their Origin," in D. Minacci, M. Betro, St. Quirke (eds.), Company of images: modelling the ancient Egyptian imaginary. World of the Middle Kingdom (2000-1500 BC), OLA 262 (2017): 377-94.

- Moussa \& H. Altenmüller, Das Grab des Nianchchnum und Chnumhotep, AV 21 (Mainz: Philipp von Zabern, 1977).

- N. Kanawati, M. Abder-Raziq, The Teti Cemetery at Saqqara. Volume V: The tomb of Hesi. Australian Centre for Egyptology: reports 13. (Warminster: Aris \& Phillips, 1999).

- P. Montet, Les scènes de la vie privée dans les tombeaux égyptiens de l'ancien empire (Strassburg, 1925).

- W. Smith, The Art and Architecture of Ancient Egypt (USA: Harmondsworth: Penguin Books. USA, 1958).

- H. Gardiner, Notes on the story of Sinuhe (Paris: Honoré Champion 1916).

- Manassa, The late Egyptian underworld: sarcophagi and related texts from the Nectanebid period. Part 1: sarcophagi and texts. Ägypten und Altes Testament 72 (Wiesbaden: Harrassowitz, 2007)

- M. G. Rashed, "Functions and Meanings of the Egg Determinative in the Egyptian Writing System”, SHEDT 2 (2015): 62-75. 
- M. G. Rashed, 'The egg as a metaphor for Isis: A Coffin Text Imaginary', MKS 2 (2016): 203-209.

- O. Goldwasser, 'Itn - The "Golden Egg', CT IV 292-b-c [B9Ca])', in Van Dijk (ed.), Essays in Honour of Herman Te Velde, Egyptological Memoirs 1. (Groningen: Styx, 1997).

- R. O. Faulkner, "The pregnancy of Isis", JEA 54 (1968), 40-48.

- R. Holtheor, New Kingdom Pharaonic Sites: The Pottery. The Scandinavian Joint Expedition to Sudanese Nubia, 5:1 (1977).

- R. Hannig, Ägyptisches Wörterbuch I: Altes Reich und Erste Zwischenzeit Ägyptisches Wörterbuch I: Altes Reich und Erste Zwischenzeit. Hannig-Lexica 4; Kulturgeschichte der Antiken Welt 98. (Mainz: Philipp von Zabern, 2003).

- R.A. Caminos, Literary Fragments in the Hieratic Script, Oxford 1956, 51-52. pls. 24-25; R. Koch, Die Erzählung des Sinuhe, BiAe XVII (1990), 1-20.

- R. Hannig, Grosses Handwörterbuch Ägyptisch-Deutsch die Sprache der Pharaonen (2800950 v. Chr.). Kulturgeschichte der Antiken Welt 64. (Mainz: Philipp von Zabern,1995).

- P. A. Piccione, 'Mehen, Mysteries, and Resurrection from the Coiled Serpent,' JARCE 27 (1990): 43-55.

- P. Wilson, A Ptolemaic Lexikon: A Lexicographical Study of the Texts in the Temple of Edfu, OLA 78 (Leuven: Peeters 1997).

- Shih-Wei Hsu, 'Figurative Expressions Referring to Animals in Royal Inscriptions of the 18th Dynasty,' JEH 6 (2013).

- S. Sauneron, Les Fêtes Religieuses d'Esna aux derniers siecles du paganisme. Esna V (Le Caire: IFAO, 1968).

- S. Sauneron, Le Temple d'Esna III, (Le Caire: IFAO, 1962), 246, text 320.21; also, P. Dorman, Faces in Clay, MÄS 52 (2002).

- W. Clarysse, A. Schoors, H. Willem (eds.), Egyptian Religion: The last Thousand Years, I, Studies Dedicated to the Memory of Jan Quaegebeur, OLA 84 (1998).

- S. Hassan, Mastabas of Ny-'ankh-Pepy and Others. Edited by Zaki Iskander. Excavations at Saqqara 1937-1938 (2). (Cairo: General Organisation for Government Printing Offices, 1975).

- S. Hassan, Excavations at Saqqara, 1937-1938, II (Cairo: General Organisation for Government Printing Offices, 1975).

- W.J. Darby, Paul Ghalioungui, and Louis Grivetti, Food: the gift of Osiris, I, (London; New York; San Francisco: Academic Press, 1977). 